\title{
ESTIMATION OF THE HEAT STRESS PROBABILITY IN COWS IN AN UNINSULATED COWSHED DURING SUMMER HEAT
}

\author{
R. V. Mylostyvyi, Candidate of Veterinary Sciences, Associate Professor \\ ORCID ID: 0000-0002-4450-8813 \\ Dnipro State Agrarian and Economic University
}

The air temperature and relative humidity in the cowshed were examined during summer heat period to determine the comfort of dairy cows by calculating the temperature-humidity index (THI). These values were depended on the time of day. The difference in average temperatures inside and outside the cowshed didn't exceed 2 $3^{\circ} \mathrm{C}$. During the summer heat period $\left(+36.9^{\circ} \mathrm{C}\right)$, the uninsulated cowshed was cooler because of the tent (which had provided shadow against the sunlight) and the continuous work of large diameter fans. The relative air humidity in the room was on average 1-14\% higher than outside, due to the release of moisture by animals and evaporation from the surrounding equipment. Therefore, THI outside and inside the cowshed differed by $2-3$ units $(P<0.05)$. It exceeded the comfortable value (68) for cows during 18 hours per day, with a maximum increase to 81. The THI in the room itself was also different. The difference between the central and side parts of an uninsulated cowshed reached 3-4 units $(P<0.05)$. This was depended on its location relatively to the four points of compass (from north to south) and the time of day, which means, on the degree of warming up the room by the rays of sunlight.

Keywords: uninsulated cowshed, dairy cows, external environment, hot climate, temperature-humidity index

Formulation of the problem. The environment affects the well-being, behavior and productivity of dairy cows [1-3]. The borderline of temperature comfort for cattle depends on the breed and its productivity [4]. For cows comfortable are temperatures from -13 to $+20-25^{\circ} \mathrm{C}$ [5]. Cattle tolerate lower temperatures more easily than heat. High temperatures lead to changes in the clinical condition of animals [6], impaired metabolic homeostasis [7], reduced milk yield [8-11] and changes in the components of milk [12-13].

Heat stress is becoming a serious problem for dairy farming under conditions of global climate change [14-15]. Studies in the United States [16] show annual economic losses in dairy farming in the amount of $\$ 897$ million. In the European Union, losses can reach 422 euros per animal, of which $80 \%$ are associated with decrease in milk production and $20 \%$ - with declining health. In Switzerland, Czech Republic and Poland, in the summertime, dairy cows are exposed to heat stress from 6 to 10 hours per day, and in Spain, Italy and the south of France - from 13 to 18 hours, losing from 3.0 to $5.5 \mathrm{~kg}$ of milk [17]. In Eastern Europe, duration of the stress period can reach 30-60 days, which leads to a decrease in productivity by $10-35 \%$, and losses due to decline in the calves' birth rate can amount to $\$ 120$ per cow in a year [18].

Analysis of recent research and publications. It is important to monitor the high temperatures and relative humidity of the air, which together affect the thermoregulation of animals. The temperaturehumidity index (THI) is widely used to assess the effect of heat on dairy cattle [19]. The methods for its calculating are varied [20], like degree of heat stress that it characterizes [21].

Ensuring the comfort of animals in an uninsulated cowshed remains a problem, since the indoor climate does not different much from the external environment [8]. Although an uninsulated cowshed has an advantage over keeping livestock on an open air pasture during the summer heat (regarding the possibility of using large diameter fans and irrigation), the temperature difference inside and outside the cowshed during the warm period of the year does not exceed $5^{\circ} \mathrm{C}$ [22-24]. Therefore, the effect of high temperatures on cows is significant.

The purpose of the study was to analyze the temperature and humidity regime of an uninsulated cowshed and the possibility for heat stress development in Holstein cows during summer heat.

Materials and methods of research. The temperature $\left({ }^{\circ} \mathrm{C}\right)$ and relative humidity were measured in the cowshed of the dairy enterprise of the private joint-stock company Agro-Soyuz (Dnipropetrovsk oblast', Ukraine) in August 2018 during the summer heat. The uninsulated cowshed of hangar type with an awning covering, has side canvas curtains, four-row placement of stalls for keeping dairy cows without a leash. The dimensions in the axes are $124 \times 34.5 \mathrm{~m}$, the height in the skate is 8.25 $\mathrm{m}$. The total area of the premise per cow is $4.3 \mathrm{~m} 2$

(C) Милостивий Р. В., 2019 
(the stall is $2.24 \mathrm{~m} 2$ ). The cowshed is equipped with a feeding table and group automatic drinking-bowls.

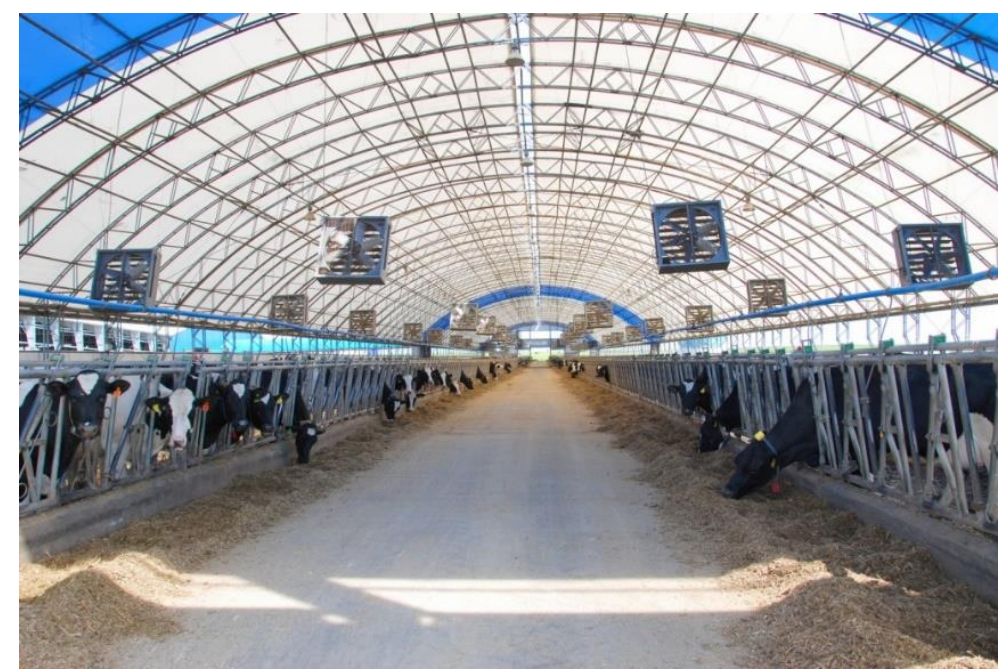

Fig. 1. Uninsulated cowshed of the hangar type with an awning coating

Remote thermohygrometer sensors (F007TH) of the Ambient Weather WS-10 (Ambient LLC, USA) were placed directly in the stalls around the edges and in the center of the premise at the cows resting level, and separately in the shade outside of the cowshed (Fig. 2 b, c). Sensor readings were recorded at intervals of 5-20 min continuously throughout the day. Protective covers for sensors in the form of durable metal mesh were fixed in stalls (Fig. 2a), so that animals could get used to them. Cows are very curious, and their excessive attention could affect the accuracy of measurements. Before measurements, the sensors and the instrument were configured using Assman aspiration psychrometer by GOST 6353-52.
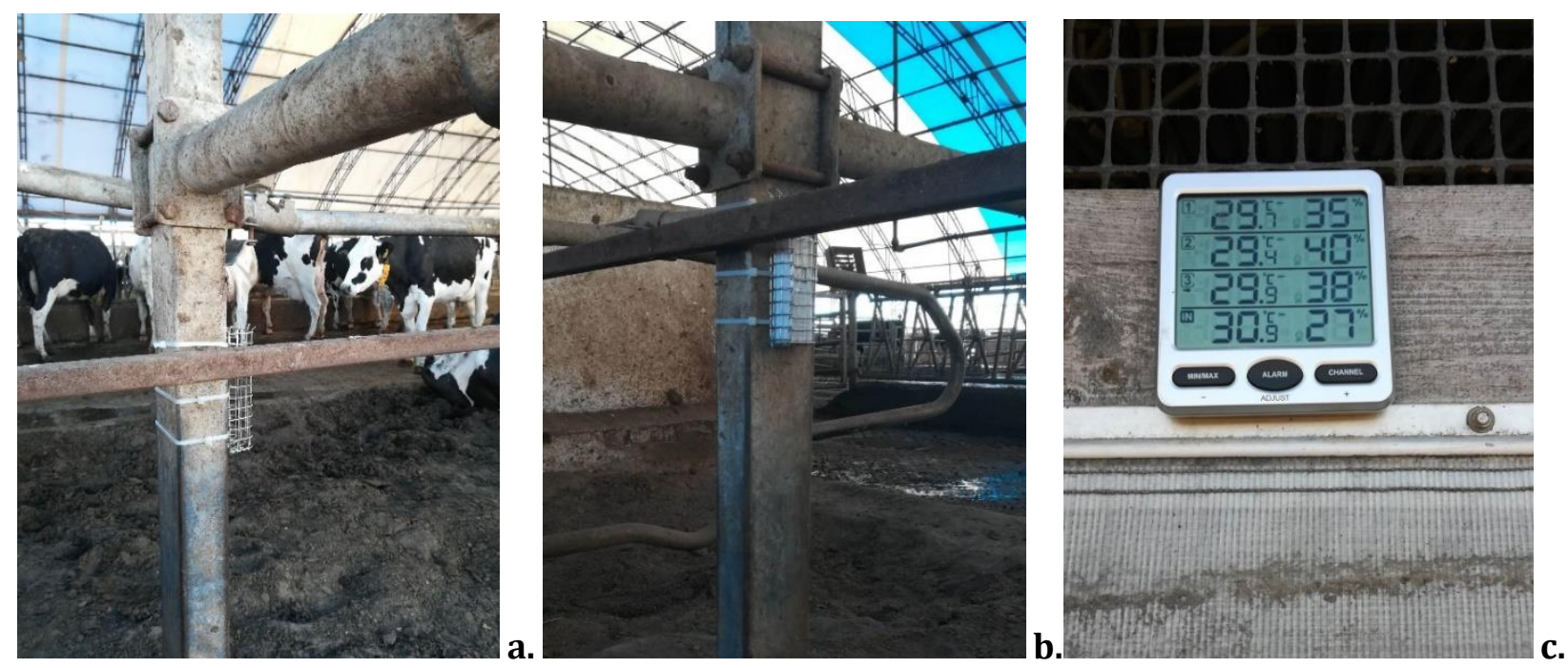

Fig. 2. Measurement of temperature and humidity regime in an uninsulated cowshed: protective covers for sensors made of durable metal mesh (a), one of the sensors (F007TH) located in the cow rest stall (b), thermohygrometer Ambient Weather WS-10 outside of cowshed (c).

The state of comfort of the cows was determined by calculating the temperature-humidity index (THI) by the equation:

$$
T H I=1,8 * T-\left(1-\frac{R H}{100}\right) *(T-14,3)+32,
$$

where $\mathrm{THI}=$ temperature-humidity index; $\mathrm{T}=$ air temperature, ${ }^{\circ} \mathrm{C} ; \mathrm{RH}=$ relative humidity, $\%$.
Mathematical processing of the obtained results was performed using the Statistica 10 software package for statistical analysis (StatSoft, Inc., USA). Differences between samples were determined using ANOVA and were considered significant at $\mathrm{P}<0.05$.

Presenting main material. Studies were carried out in the range of external temperatures from +19.2 to $+36.9^{\circ} \mathrm{C}$. The temperature in the cowshed was 
depended on the environmental state. Large diameter fans worked in the room around the clock (the speed of air movement in the animal resting place was on a level was on level $0,5-0,9 \mathrm{~m} / \mathrm{s})$. The correlation between the air temperature inside and outside the cowshed amounted to $r=0.962(\mathrm{R} 2=0.93)$. The average temperature inside and outside the cowshed differed slightly (Fig. 3). With an external temperature of $+20-23^{\circ} \mathrm{C}$ (at night and in the early morning) the temperature difference inside and outside the room did not exceed $0.3^{\circ} \mathrm{C}$. From the morning and until noon, when the external temperature warmed up to $+32^{\circ} \mathrm{C}$, it was $1.5-2.0^{\circ} \mathrm{C}$ warmer in the cowshed. We associated this with the ability of the room to retain the heat which produced by animals. During the summer heat, when the outside air warmed up above $+35^{\circ} \mathrm{C}$, the tent of the cowshed appeared as a shadow protection for animals. Indoors was cooler. The difference in average temperatures was up to $1.9^{\circ} \mathrm{C}$. When the temperature decreased to $+32{ }^{\circ} \mathrm{C}$ in the evening and until midnight, in the uninsulated cowshed it was 1.5$2.5^{\circ} \mathrm{C}$ cooler. Which we connected with faster cooling of the room where the fans were worked.

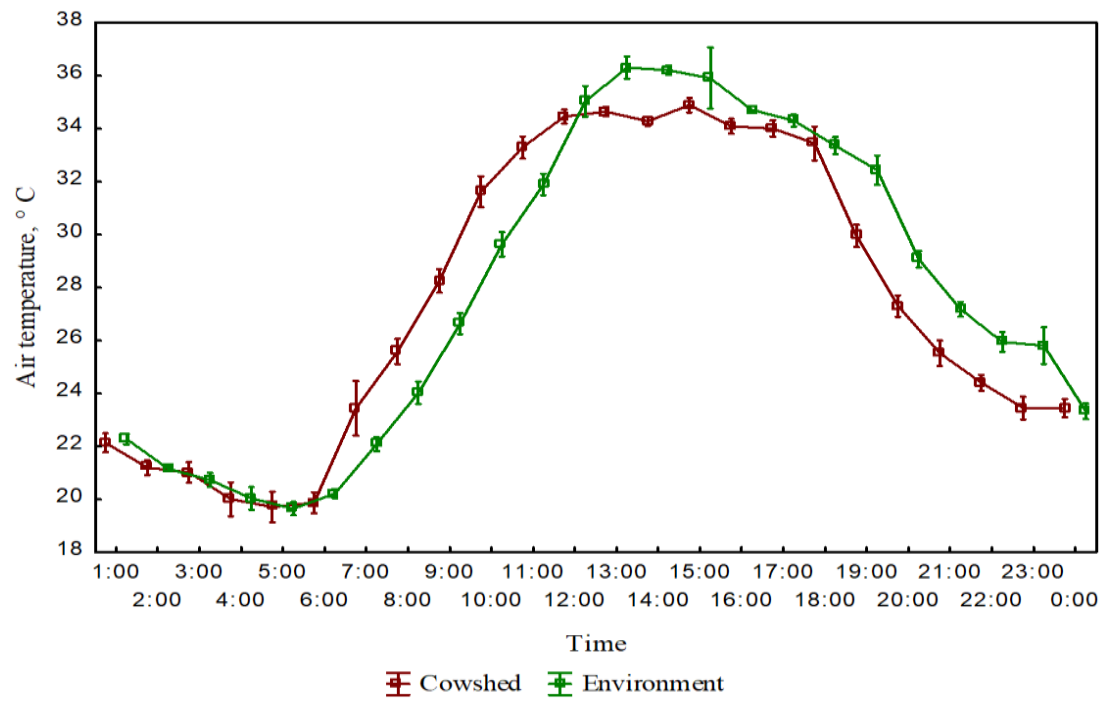

Fig. 3. Dynamics of average temperatures inside (green line) and outside (red line) the uninsulated cowshed

The temperature in different parts of the room, having a north-south location relative to the cardinal directions, differed significantly (Tab. 1). From 7:00 a.m. to noon in the southeastern part of the room it was warmer by $0.5-3.0^{\circ} \mathrm{C}$ than in the northwestern part. This is due to the warming up of the cowshed by the rays of the rising sun. In the afternoon and until 6 p.m., the north-west side warmed up greater. The temperature was higher by $0.3-1.2 \circ \mathrm{C}$. The temperature difference in the center and the end faces of the cowshed during the day was $0.1-3.7^{\circ} \mathrm{C}$.

Table 1

Air temperature dynamics in an uninsulated cowshed during the day, Mean $( \pm$ SE)

\begin{tabular}{|c|c|c|c|c|}
\hline & Outdoors & \multicolumn{2}{|c|}{ Cowshed } \\
\hline Time of the day & in the shade, $\mathrm{n}=134$ & $\begin{array}{c}\text { south-east side, } \\
\mathrm{n}=134\end{array}$ & central part, $\mathrm{n}=134$ & $\begin{array}{c}\text { north-west side, } \\
\mathrm{n}=134\end{array}$ \\
\hline 1 & 2 & 3 & 4 & 5 \\
\hline $1: 00$ & $22.3 \pm 0.20^{a}$ & $22.1 \pm 0.31^{a 1}$ & $22.6 \pm 0.23^{a 1}$ & $21.8 \pm 0.25^{a 1}$ \\
\hline $2: 00$ & $21.2 \pm 0.07^{a}$ & $21.1 \pm 0.14^{a 1}$ & $21.6 \pm 0.29^{a 1}$ & $20.9 \pm 0.12^{a 1}$ \\
\hline $3: 00$ & $20.7 \pm 0.25^{a}$ & $21.3 \pm 0.24^{a 1}$ & $20.9 \pm 0.51^{a 1}$ & $20.8 \pm 0.24^{a 1}$ \\
\hline $4: 00$ & $20.0 \pm 0.40^{a}$ & $20.2 \pm 0.54^{a 1}$ & $19.8 \pm 0.79^{a 1}$ & $20.0 \pm 0.41^{a 1}$ \\
\hline $5: 00$ & $19.6 \pm 0.23^{a}$ & $20.3 \pm 0.58^{a 1}$ & $19.0 \pm 0.54^{a 2}$ & $19.8 \pm 0.38^{a 1}$ \\
\hline $6: 00$ & $20.2 \pm 0.17^{a}$ & $20.0 \pm 0.40^{a 1}$ & $19.3 \pm 0.23^{b 1}$ & $20.4 \pm 0.24^{a 2}$ \\
\hline $7: 00$ & $22.1 \pm 0.25^{a}$ & $25.7 \pm 0.44^{b 1}$ & $22.0 \pm 0.50^{a 2}$ & $22.7 \pm 0.44^{a 2}$ \\
\hline $8: 00$ & $24.0 \pm 0.40^{a}$ & $26.6 \pm 0.22^{b 1}$ & $24.8 \pm 0.36^{a 2}$ & $25.6 \pm 0.38^{b 1}$ \\
\hline $9: 00$ & $26.6 \pm 0.39^{a}$ & $28.8 \pm 0.37^{b 1}$ & $28.1 \pm 0.42^{b 1}$ & $27.8 \pm 0.31^{a 1}$ \\
\hline $10: 00$ & $29.6 \pm 0.43^{a}$ & $32.0 \pm 0.46^{b 1}$ & $31.9 \pm 0.65^{b 1}$ & $31.0 \pm 0.38^{a 1}$ \\
\hline
\end{tabular}


Continuation of the table 1

\begin{tabular}{|c|c|c|c|c|}
\hline 1 & 2 & 3 & 4 & 5 \\
\hline $11: 00$ & $31.9 \pm 0.38^{a}$ & $34.2 \pm 0.31^{b 1}$ & $32.7 \pm 0.25^{a 2}$ & $33.0 \pm 0.31^{b 2}$ \\
\hline $12: 00$ & $35.0 \pm 0.54^{a}$ & $34.9 \pm 0.27^{a 1}$ & $34.0 \pm 0.14^{a 2}$ & $34.5 \pm 0.21^{a 1}$ \\
\hline $13: 00$ & $35.0 \pm 0.54^{a}$ & $35.0 \pm 0.13^{b 1}$ & $34.2 \pm 0.09^{b 2}$ & $34.5 \pm 0.21^{b 1}$ \\
\hline $14: 00$ & $36.2 \pm 0.16^{a}$ & $34.3 \pm 0.05^{b 1}$ & $34.0 \pm 0.09^{b 2}$ & $34.6 \pm 0.15^{b 3}$ \\
\hline $15: 00$ & $35.9 \pm 1.41^{a}$ & $34.7 \pm 0.23^{a 1}$ & $34.8 \pm 0.28^{a 1}$ & $35.2 \pm 0.21^{a 1}$ \\
\hline $16: 00$ & $34.7 \pm 0.19^{a}$ & $34.0 \pm 0.21^{a 1}$ & $34.2 \pm 0.35^{a 1}$ & $34.2 \pm 0.35^{a 1}$ \\
\hline $17: 00$ & $34.3 \pm 0.28^{a}$ & $33.8 \pm 0.21^{a 1}$ & $34.3 \pm 0.21^{a 1}$ & $34.0 \pm 0.28^{a 1}$ \\
\hline $18: 00$ & $33.4 \pm 0.31^{a}$ & $32.5 \pm 0.40^{a 1}$ & $34.2 \pm 0.65^{a 1}$ & $33.7 \pm 0.43^{a 1}$ \\
\hline $19: 00$ & $32.4 \pm 0.52^{a}$ & $30.0 \pm 0.34^{a 1}$ & $30.2 \pm 0.47^{b 1}$ & $29.6 \pm 0.33^{b 1}$ \\
\hline $20: 00$ & $29.1 \pm 0.29^{a}$ & $27.3 \pm 0.55^{b 1}$ & $27.5 \pm 0.25^{b 1}$ & $27.1 \pm 0.24^{b 1}$ \\
\hline $21: 00$ & $27.2 \pm 0.28^{a}$ & $25.9 \pm 0.47^{a 1}$ & $25.3 \pm 0.49^{b 1}$ & $25.4 \pm 0.35^{b 1}$ \\
\hline $22: 00$ & $25.9 \pm 0.37^{a}$ & $23.9 \pm 0.32^{b 1}$ & $24.6 \pm 0.12^{b 2}$ & $24.7 \pm 0.12^{a 2}$ \\
\hline $23: 00$ & $25.8 \pm 0.73^{a}$ & $23.7 \pm 0.12^{a 1}$ & $23.8 \pm 0.12^{a 1}$ & $22.8 \pm 0.41^{a 1}$ \\
\hline $24: 00$ & $23.3 \pm 0.30^{a}$ & $23.3 \pm 0.17^{a 1}$ & $23.6 \pm 0.25^{a 1}$ & $23.5 \pm 0.49^{a 1}$ \\
\hline
\end{tabular}

Note: different Latin characters in the rows indicate samples that are significantly different from one another $(P<0.05)$ according to the Mann-Whitney U-test. Different numbers indicate significant differences in the values inside the cowshed

The relative air humidity in the cowshed was depended on the environmental state (Fig. 4). The correlation between the relative humidity inside and outside the cowshed amounted to $\mathrm{r}=0.954$ ( $\mathrm{R} 2=$ $0.91)$. Its average values in the cowshed were the highest (48.2-55.9\%) at night and in the early morning before sunrise. The difference between relative humidity values indoors and outdoors was small (0.7-3.4\%). In the noon hours and until 4:00 p.m. with maximum warming up of atmospheric air, its humidity decreased to $13.5 \%$, however in the cowshed it remained higher on average by 7.9 $11.7 \%$. The difference was significant in the evening and until sunset (6.1-12.4\%), and only after sunset and until midnight, it was only $3.4-4.1 \%$. During 24 hours, the relative air humidity in the cowshed was higher than outside. This is due to the release of moisture by animals and evaporation from wet surfaces of enclosing structures.

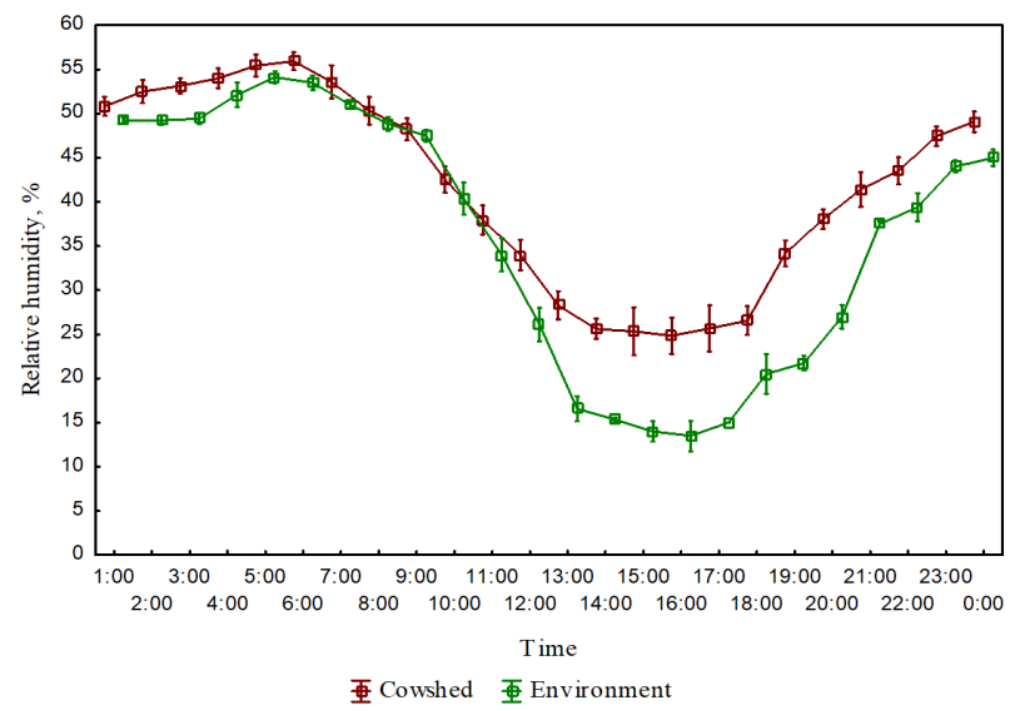

Fig. 4. Dynamics of average relative humidity values outside (green line) and inside (brown line) uninsulated cowshed, $n=402$

The relative air humidity differed in different parts of the lightweight cowshed (Tab. 2). From 9:00 a.m. to 6:00 p.m. it was higher in the central part of the room by $0.5-7.2 \%$ than in the end parts of the uninsulated cowshed. In the morning and evening hours, as well as at night, the air humidity in the south-eastern part of the room was $0.5-6.2 \%$ higher. During the day, the relative air humidity in the northwestern part of the cowshed was lower. 
Table 2

Dynamics of relative humidity in an uninsulated cowshed during the day, Mean $( \pm S E)$

\begin{tabular}{|c|c|c|c|c|}
\hline & Outdoors & \multicolumn{3}{|c|}{ Cowshed } \\
\hline Time of the day & in the shade, $n=134$ & south-east side, $n=134$ & central part, $n=134$ & north-west side, $n=134$ \\
\hline $1: 00$ & $49.3 \pm 0.29^{a}$ & $49.5 \pm 0.75^{a 1}$ & $50.8 \pm 0.73^{b 2}$ & $52.3 \pm 0.29^{b 2}$ \\
\hline $2: 00$ & $49.3 \pm 0.55^{a}$ & $51.0 \pm 0.47^{a 1}$ & $51.5 \pm 0.75^{a 1}$ & $55.0 \pm 0.47^{b 2}$ \\
\hline $3: 00$ & $49.5 \pm 0.49^{a}$ & $51.5 \pm 0.45^{b 1}$ & $51.9 \pm 0.43^{b 2}$ & $55.3 \pm 0.39^{b 3}$ \\
\hline $4: 00$ & $52.5 \pm 1.20^{a}$ & $52.5 \pm 0.61^{a 1}$ & $55.0 \pm 1.14^{a 1}$ & $57.1 \pm 0.74^{b 2}$ \\
\hline $5: 00$ & $54.1 \pm 0.64^{a}$ & $52.7 \pm 0.65^{a 1}$ & $56.1 \pm 0.96^{a 2}$ & $57.4 \pm 0.74^{b 2}$ \\
\hline $6: 00$ & $53.5 \pm 0.79^{a}$ & $53.5 \pm 0.37^{a 1}$ & $56.5 \pm 0.24^{b 2}$ & $57.8 \pm 0.44^{b 3}$ \\
\hline $7: 00$ & $51.0 \pm 0.35^{a}$ & $50.2 \pm 1.98^{a 1}$ & $55.0 \pm 0.71^{b 1}$ & $55.6 \pm 0.45^{b 1}$ \\
\hline $8: 00$ & $48.8 \pm 0.77^{a}$ & $46.8 \pm 0.66^{a 1}$ & $51.3 \pm 0.67^{b 2}$ & $52.8 \pm 1.00^{b 2}$ \\
\hline $9: 00$ & $47.5 \pm 0.62^{a}$ & $45.0 \pm 0.49^{b 1}$ & $50.2 \pm 0.34^{b 2}$ & $49.5 \pm 0.37^{b 2}$ \\
\hline $10: 00$ & $40.4 \pm 1.71^{a}$ & $40.8 \pm 0.83^{a 1}$ & $44.3 \pm 1.21^{a 2}$ & $42.6 \pm 1.67^{a 1}$ \\
\hline $11: 00$ & $34.0 \pm 1.75^{a}$ & $35.9 \pm 1.47^{a 1}$ & $40.4 \pm 0.97^{b 2}$ & $37.6 \pm 1.57^{a 1}$ \\
\hline $12: 00$ & $26.1 \pm 1.75^{a}$ & $30.9 \pm 1.10^{a 1}$ & $38.1 \pm 0.48^{b 2}$ & $32.9 \pm 1.48^{b 3}$ \\
\hline $13: 00$ & $16.6 \pm 1.35^{a}$ & $25.9 \pm 1.26^{b 1}$ & $29.9 \pm 1.61^{b 2}$ & $29.1 \pm 0.98^{b 2}$ \\
\hline $14: 00$ & $15.3 \pm 0.23^{a}$ & $22.7 \pm 0.37^{b 1}$ & $27.3 \pm 0.37^{b 2}$ & $26.8 \pm 0.52^{b 2}$ \\
\hline $15: 00$ & $14.0 \pm 1.41^{a}$ & $22.5 \pm 0.71^{a 1}$ & $28.0 \pm 1.41^{a 1}$ & $25.5 \pm 0.71^{a 1}$ \\
\hline $16: 00$ & $13.5 \pm 2.12^{a}$ & $23.0 \pm 0.51^{a 1}$ & $27.0 \pm 1.41^{a 1}$ & $24.5 \pm 0.71^{a 1}$ \\
\hline $17: 00$ & $15.0 \pm 0.51^{a}$ & $23.0 \pm 0.49^{a 1}$ & $28.5 \pm 0.71^{a 1}$ & $25.5 \pm 0.71^{a 1}$ \\
\hline $18: 00$ & $20.5 \pm 2.13^{a}$ & $25.2 \pm 0.52^{a 1}$ & $28.8 \pm 1.18^{b 2}$ & $25.7 \pm 1.93^{a 1}$ \\
\hline $19: 00$ & $21.8 \pm 0.78^{a}$ & $30.1 \pm 0.65^{b 1}$ & $36.1 \pm 0.82^{a 2}$ & $36.3 \pm 0.83^{b 2}$ \\
\hline $20: 00$ & $27.0 \pm 1.25^{a}$ & $36.0 \pm 1.15^{b 1}$ & $38.3 \pm 0.56^{b 1}$ & $39.9 \pm 0.50^{b 2}$ \\
\hline $21: 00$ & $37.5 \pm 0.33^{a}$ & $39.8 \pm 0.29^{b 1}$ & $40.3 \pm 2.42^{a 1}$ & $44.3 \pm 0.29^{b 2}$ \\
\hline $22: 00$ & $39.4 \pm 1.52^{a}$ & $41.0 \pm 1.54^{a 1}$ & $44.6 \pm 0.97^{b 1}$ & $45.0 \pm 0.61^{b 1}$ \\
\hline $23: 00$ & $44.0 \pm 0.71^{a}$ & $46.0 \pm 1.22^{a 1}$ & $48.0 \pm 0.51^{a 1}$ & $48.3 \pm 0.41^{a 1}$ \\
\hline $24: 00$ & $45.0 \pm 0.94^{a}$ & $47.3 \pm 0.99^{a 1}$ & $49.5 \pm 0.33^{b 1}$ & $50.5 \pm 0.75^{b 2}$ \\
\hline
\end{tabular}

Note: see Table 1.

Temperature and air humidity regime in an uninsulated cowshed significantly changed during the day (Fig. 5). The correlation coefficient between the

temperature and the relative air humidity in the room was high $r=-0.884(\mathrm{P}<0.05)$.

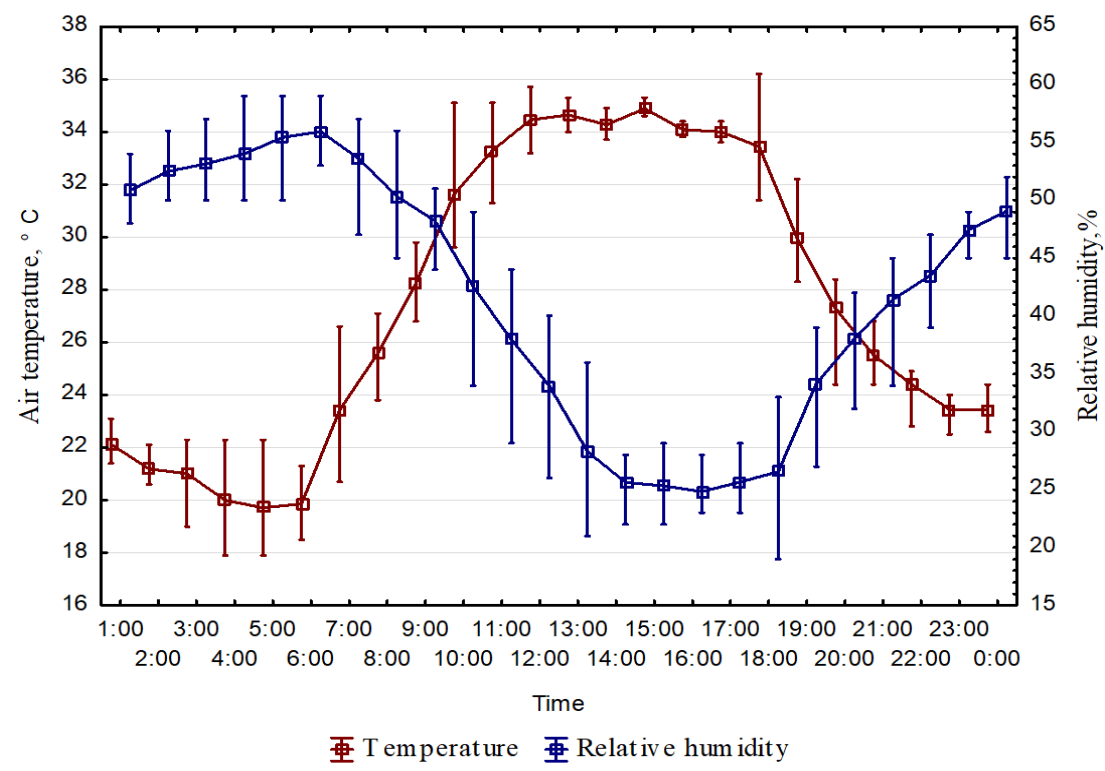

Fig. 5. Indicators of temperature and air humidity regime inside an uninsulated cowshed (Temperature - red line; relative humidity - blue line), $\mathrm{n}=402$ 
The construction of a linear regression model (Fig. 6) shows their high mutual conditionality (R2 =0.78). As the temperature in the cowshed raised by $1^{\circ} \mathrm{C}$, the relative air humidity dropped by $1.7 \%$.

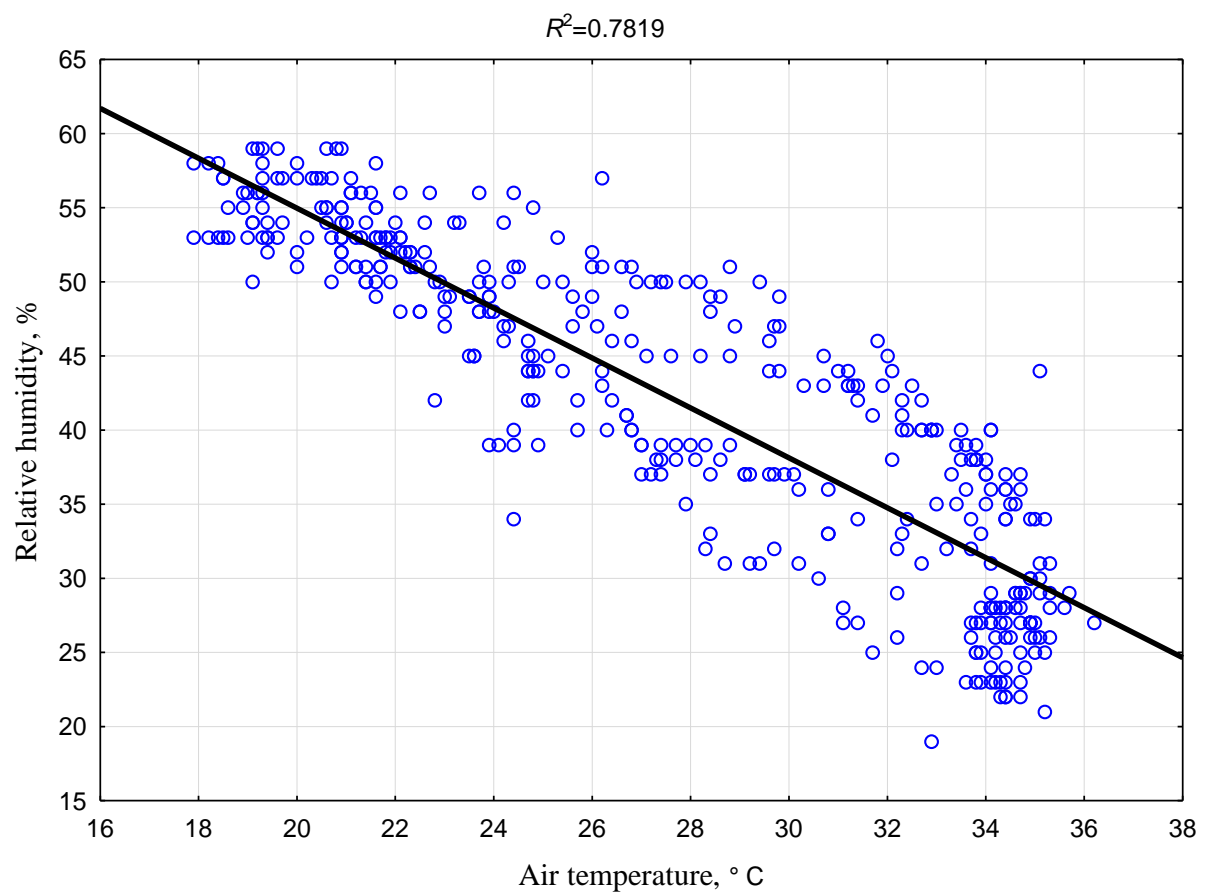

Fig. 6. Correlation between air temperature and relative air humidity in an uninsulated cowshed, $n=402$

To evaluate the effect of air temperature and humidity on animals in such conditions is rather difficult without the use of an integral indicator which would take into account their combined effect on the dairy cows organism. The temperature-humidity index (THI) has long been used to assess the comfort of livestock in conditions of heat. In the external environment, it was within 64.9-79.7. In an uninsulated cowshed, the THI value was 64.1-81.0. The difference between the THI outside and inside uninsulated cowshed, depending on the end of the building was $0.1-2.7$ (Tab. 3)

Table 3

Dynamics of the temperature-humidity index in an uninsulated cowshed during the day, Mean $( \pm S E)$

\begin{tabular}{|c|c|c|c|c|}
\hline & Outdoors & \multicolumn{3}{|c|}{ Cowshed } \\
\hline Time of the day & in the shade, $\mathrm{n}=134$ & $\begin{array}{c}\text { south-east side, } \\
\mathrm{n}=134\end{array}$ & central part, $\mathrm{n}=134$ & $\begin{array}{c}\text { north-west side, } \\
\mathrm{n}=134\end{array}$ \\
\hline 1 & 2 & 3 & 4 & 5 \\
\hline $1: 00$ & $68.1 \pm 0.26^{a}$ & $67.8 \pm 0.41^{a 1}$ & $68.6 \pm 0.23^{a 1}$ & $67.6 \pm 0.31^{a 1}$ \\
\hline $2: 00$ & $66.6 \pm 0.10^{a}$ & $66.7 \pm 0.16^{a 1}$ & $67.3 \pm 0.36^{a 1}$ & $66.7 \pm 0.19^{a 1}$ \\
\hline $3: 00$ & $66.1 \pm 0.31^{a}$ & $67.0 \pm 0.31^{a 1}$ & $66.5 \pm 0.67^{a 1}$ & $66.5 \pm 0.33^{a 1}$ \\
\hline $4: 00$ & $65.3 \pm 0.61^{a}$ & $65.6 \pm 0.71^{a 1}$ & $65.0 \pm 1.05^{a 1}$ & $65.6 \pm 0.60^{a 1}$ \\
\hline $5: 00$ & $64.9 \pm 0.28^{a}$ & $65.7 \pm 0.73^{a 1}$ & $64.1 \pm 0.67^{a 1}$ & $65.3 \pm 0.47^{a 1}$ \\
\hline $6: 00$ & $65.7 \pm 0.21^{a}$ & $65.4 \pm 0.52^{a 1}$ & $64.5 \pm 0.32^{b 2}$ & $66.1 \pm 0.33^{a 1}$ \\
\hline $7: 00$ & $67.9 \pm 0.32^{a}$ & $72.5 \pm 0.65^{b 1}$ & $68.1 \pm 0.63^{a 2}$ & $69.1 \pm 0.59^{a 2}$ \\
\hline $8: 00$ & $70.3 \pm 0.45^{a}$ & $73.0 \pm 0.21^{b 1}$ & $71.6 \pm 0.47^{a 2}$ & $72.7 \pm 0.41^{b 1}$ \\
\hline $9: 00$ & $73.5 \pm 0.47^{a}$ & $75.9 \pm 0.44^{b 1}$ & $75.7 \pm 0.54^{b 1}$ & $75.2 \pm 0.37^{b 1}$ \\
\hline $10: 00$ & $76.2 \pm 0.26^{a}$ & $79.0 \pm 0.43^{b 1}$ & $79.6 \pm 0.71^{b 1}$ & $78.2 \pm 0.24^{b 2}$ \\
\hline $11: 00$ & $77.8 \pm 0.24^{a}$ & $80.8 \pm 0.25^{b 1}$ & $79.9 \pm 0.19^{b 2}$ & $79.7 \pm 0.19^{b 2}$ \\
\hline $12: 00$ & $79.7 \pm 0.28^{a}$ & $80.6 \pm 0.32^{a 1}$ & $81.0 \pm 0.12^{b 1}$ & $80.5 \pm 0.12^{a 2}$ \\
\hline $13: 00$ & $78.9 \pm 0.17^{a}$ & $79.6 \pm 0.31^{a 1}$ & $79.6 \pm 0.35^{a 1}$ & $80.0 \pm 0.17^{b 2}$ \\
\hline $14: 00$ & $78.6 \pm 0.17^{a}$ & $78.2 \pm 0.03^{a 1}$ & $78.8 \pm 0.16^{a 2}$ & $79.4 \pm 0.21^{b 2}$ \\
\hline $15: 00$ & $78.1 \pm 1.63^{a}$ & $78.7 \pm 0.21^{a 1}$ & $79.9 \pm 0.05^{a 1}$ & $79.8 \pm 0.35^{a 1}$ \\
\hline
\end{tabular}


Continuation of the table 3

\begin{tabular}{|c|c|c|c|c|}
\hline 1 & 2 & 3 & 4 & 5 \\
\hline $16: 00$ & $76.8 \pm 0.42^{a}$ & $78.0 \pm 0.21^{a 1}$ & $79.0 \pm 0.07^{a 1}$ & $78.5 \pm 0.21^{a 1}$ \\
\hline $17: 00$ & $76.8 \pm 0.21^{a}$ & $77.8 \pm 0.21^{a 1}$ & $79.4 \pm 0.07^{a 1}$ & $78.5 \pm 0.42^{a 1}$ \\
\hline $18: 00$ & $76.9 \pm 0.51^{a}$ & $76.8 \pm 0.37^{a 1}$ & $79.3 \pm 0.51^{b 2}$ & $78.2 \pm 0.57^{a 2}$ \\
\hline $19: 00$ & $76.2 \pm 0.45^{a}$ & $75.0 \pm 0.30^{a 1}$ & $76.2 \pm 0.42^{b 2}$ & $75.6 \pm 0.26^{a 1}$ \\
\hline $20: 00$ & $73.5 \pm 0.16^{a}$ & $72.8 \pm 0.53^{a 1}$ & $73.3 \pm 0.25^{a 1}$ & $73.1 \pm 0.23^{a 1}$ \\
\hline $21: 00$ & $72.9 \pm 0.34^{a}$ & $71.7 \pm 0.57^{a 1}$ & $70.9 \pm 0.79^{a 1}$ & $71.5 \pm 0.42^{a 1}$ \\
\hline $22: 00$ & $71.6 \pm 0.42^{a}$ & $69.3 \pm 0.40^{b 1}$ & $70.6 \pm 0.09^{a 2}$ & $70.7 \pm 0.10^{a 2}$ \\
\hline $23: 00$ & $72.0 \pm 0.92^{a}$ & $69.6 \pm 0.24^{a 1}$ & $69.9 \pm 0.16^{a 1}$ & $68.7 \pm 0.57^{a 1}$ \\
\hline $24: 00$ & $69.0 \pm 0.30^{a}$ & $69.1 \pm 0.21^{a 1}$ & $69.8 \pm 0.32^{a 1}$ & $69.7 \pm 0.62^{a 1}$ \\
\hline
\end{tabular}

Note: see Table 1.

In different ends of the uninsulated cowshed, depending on the time of day, the greatest difference in THI value was $2.5-4.4$ (Fig. 4) exceeding the comfortable values for dairy cows even in the morning and evening hours.

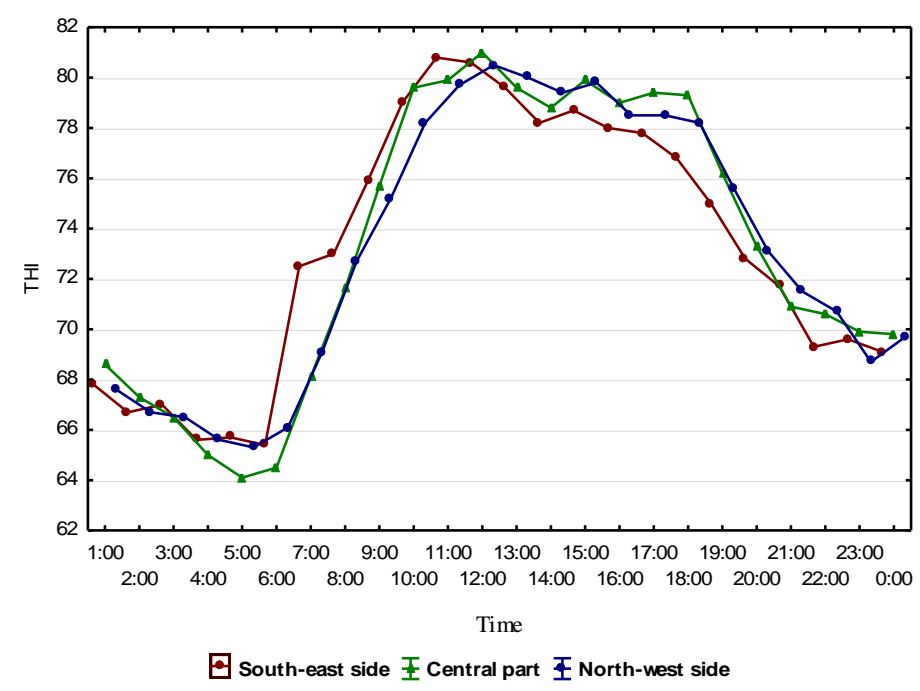

Fig. 7. Temperature-humidity index in different ends of the uninsulated cowshed (south-east side red line; central part - green line; north-west side - blue line), $n=134$

Therefore, the differences in the indicators of the temperature-humidity index in different ends of the uninsulated cowshed can significantly affect the state of comfort of the animals.

Discussion. "Cold" or "uninsulated" cowsheds are usually referred to that one with natural ventilation, the barrier structures of which are made with minimal thermal insulation or without it. A well-built cowshed should work as a tent in the summer, protecting animals from rain and sun. The difference between the indoor and outdoor air temperature in it usually doesn't exceed $5^{\circ} \mathrm{C}$ [25].

The air temperature in modern lightweight cowsheds depends on the ambient air temperature, which directly affects the animals living conditions. Therefore, to prevent the loss of milk, it is necessary to implement effective methods of heat diffusion and temperature stabilization in cowsheds [18].

Many researchers $[8,14,20]$ had been calculating the THI, using meteorological data (temperature and relative humidity) which were obtained at stations located near farms. This is a very convenient and affordable way. However, even in an uninsulated cowshed, the difference in THI values inside and outside the room can be significant. As well as in different places of the room, the indicators of THI were different too. In particular, in the central part of the cowshed with natural ventilation [26], THI was higher by 2.33 than in the end parts.

The authors $[14,27,28]$ were tend to think that THI at level 72 is the beginning for reducing milk yield in dairy cows, and for the content of milk fat and protein its threshold values are even lower. Thus, the differences we obtained in the THI value of 2-4 units in different parts of the non-insulated cowshed could affect the milk yield and milk composition of individual animals.

It should be noted that the studies were carried out with large diameter fans operating around the clock. The air speed at the animal resting site was low (up to $0.9 \mathrm{~m} / \mathrm{s}$ ), and only near the feeding table its maximum speed was $2.8-3.6 \mathrm{~m} / \mathrm{s}$. There were no significant 
differences in the air speed in the ends of the cowshed and its central part.

Experiments in the climate chamber [29] showed that the normalization of the animals clinicalphysiological parameters (respiration rate, pulse, skin temperature) directly depended on the fan speed and the time of airflow impact, the higher they were, the faster clinical parameters returned to the limits of physiological standards. Comfortable environment in the rest and feeding areas of animals was achieved when the fans were located at a height of 2.5-3 meters from the floor at an angle of $12-17^{\circ}$ and the distance between the fans was $14 \mathrm{~m}$.

However, the opinion of researchers on this subject was different. One of the author [23] as a positive influence on the behavior of dairy cows during the summer heat recommended to increase the air speed to 3-4 m/s, while in the recommendations of others [29], its mobility should not exceed 1.5-2.0 $\mathrm{m} / \mathrm{s}$. This is quite enough to reduce the temperature of the skin by $5^{\circ} \mathrm{C}$ with increasing heat dissipation due to convection and evaporation.

Apparently, the use of large diameter fans alone in uninsulated cowshed, in our case, was insufficient, since the value of the temperature-humidity index exceeded the rate (68) that was comfortable for cows for 18 hours per day.

In the results which were published in 1988 [30], it was shown that a combination of wetting and forced ventilation can reduce the daily increase in rectal temperature by $0.3^{\circ} \mathrm{C}$, increasing cows milk yield by $3.6 \mathrm{~kg}$ per day. However, in conditions of low air mobility, excessive humidity when using sprinklers may cause animals overheating due to impairment of heat loss. The suggested technical solution [31-32], allowed to adjust the temperature and maintain the air relative humidity in livestock buildings by creating micro-droplet water mist (the droplet size up to 30 microns) in the animals area. Due to the water evaporation, the livestock building is cooled up to $4 \ldots 10^{\circ} \mathrm{C}$. The advantage of this system is the automatic maintenance of the microclimate (humidity / temperature), the elimination of dust and pathogenic bacteria, the neutralization of unpleasant odors and volatile compounds (ammonia, methane, carbon dioxide, etc.), as well as dry litter, which is preferred [33]. We consider those systems to be the most acceptable in the period of a significant increase in THI indoors.

Conclusions and future prospects research. The indoor temperature and humidity regime in an uninsulated cowshed was similar to the external environment. Differences in THI indicators inside and outside the room, as well as in its different parts, were due to the location and design features of the uninsulated barn. This can affect the comfort of individual animals during summer heat. Largediameter fans did not provide effective cooling of the air at the cows resting place for a long time during the day. This should include the use of additional technical solutions in periods of significant increase in THI, possibly through irrigation. The effectiveness of various methods of normalization of the microclimate in an uninsulated room during the summer heat will be the subject of further research.

\section{References:}

1. Sejian, V., Pragna, P., Archana, P. R., Aleena, J., Krishnan, G., Bagath, M., ... Bhatta, R. (2017). Heat Stress and Dairy Cow: Impact on Both Milk Yield and Composition. International Journal of Dairy Science, 12(1), 1-11. doi:10.3923/ijds.2017.1.11

2. Vaculíková, M., Komzáková, I., \& Chládek, G. (2017). The Effect of Low Air Temperature on Behaviour and Milk Production in Holstein Dairy Cows. Acta Universitatis Agriculturae et Silviculturae Mendelianae Brunensis, 65(5), 1623-1627. doi:10.11118/actaun201765051623

3. Skibiel, A. L., Zachut, M., do Amaral, B. C., Levin, Y., \& Dahl, G. E. (2018). Liver proteomic analysis of postpartum Holstein cows exposed to heat stress or cooling conditions during the dry period. Journal of Dairy Science, 101(1), 705-716. doi:10.3168/jds.2017-13258

4. Gantner, V., Bobic, T., Gantner, R., Gregic, M., Kuterovac, K., Novakovic, J., \& Potocnik, K. (2017). Differences in response to heat stress due to production level and breed of dairy cows. International Journal of Biometeorology, 61(9), 1675-1685. doi:10.1007/s00484-017-1348-7

5. Buryakov, N. P., Buryakova, M. A., \& Aleshin, D. E. (2016). Teplovoy stress i osobennosti kormleniya molochnogo skota [Heat Stress and Heat Stress and Feeding Features of the Dairy Cattle]. Rossiyskiy veterinarnyiy jurnal, 3, 5-13 (in Russian)

6. Bravo, D. M., \& Wall, E. H. (2016). The rumen and beyond: Nutritional physiology of the modern dairy cow. Journal of Dairy Science, 99(6), 4939-4940. doi:10.3168/jds.2015-10191

7. Fan, C., Su, D., Tian, H., Li, X., Li, Y., Ran, L., ... Cheng, J. (2018). Liver metabolic perturbations of heat-stressed lactating dairy cows. Asian-Australasian Journal of Animal Sciences, 31(8), 1244-1251. doi:10.5713/ajas.17.0576

8. Lambertz, C., Sanker, C., \& Gauly, M. (2014). Climatic effects on milk production traits and somatic cell score in lactating HolsteinFriesian cows in different housing systems. Journal of Dairy Science, 97(1), 319-329. doi:10.3168/jds.2013-7217

9. Das, R., Sailo, L., Verma, N., Bharti, P., Saikia, J., Imtiwati, \& Kumar, R. (2016). Impact of heat stress on health and performance of dairy animals: A review. Veterinary World, 9(3), 260-268. doi:10.14202/vetworld.2016.260-268

10. Fournel, S., Ouellet, V., \& Charbonneau, É. (2017). Practices for Alleviating Heat Stress of Dairy Cows in Humid Continental Climates: A Literature Review. Animals, 7(12), 37. doi:10.3390/ani7050037 
11. Tao, S., Orellana, R. M., Weng, X., Marins, T. N., Dahl, G. E., \& Bernard, J. K. (2018). Symposium review: The influences of heat stress on bovine mammary gland function. Journal of Dairy Science, 101(6), 5642-5654. doi:10.3168/jds.2017-13727

12. Carabaño, M. J., Logar, B., Bormann, J., Minet, J., Vanrobays, M.-L., Díaz, C., ... Hammami, H. (2016). Modeling heat stress under different environmental conditions. Journal of Dairy Science, 99(5), 3798-3814. doi:10.3168/jds.2015-10212

13. Liu, Z., Ezernieks, V., Wang, J., Arachchillage, N. W., Garner, J. B., Wales, W. J., ... Rochfort, S. (2017). Heat Stress in Dairy Cattle Alters Lipid Composition of Milk. Scientific Reports, 7(1). doi:10.1038/s41598-017-01120-9

14. Tamami, F. Z., Hafezian, H., Mianji, G.R., Abdullahpour, R., \& Gholizadeh, M. (2018). Effect of the temperature-humidity index and lactation stage on milk production traits and somatic cell score of dairy cows in Iran. Songklanakarin J. Sci. Technol. 40 (2), 379-383.

15. Vasilenko, T. O., Milostiviy, R. V., Kalinichenko, O. O., Gutsulyak, G. S., \& Sazykina, E. M. (2018). Influence of high temperature on dairy productivity of Ukrainian Schwyz. Scientific Messenger of LNU of Veterinary Medicine and Biotechnologies, 20(83), 97-101. doi:10.15421/nvlvet8319

16. St-Pierre, N. R., Cobanov, B., \& Schnitkey, G. (2003). Economic Losses from Heat Stress by US Livestock Industries. Journal of Dairy Science, 86, E52-E77. doi:10.3168/jds.s0022-0302(03)74040-5

17. Piron, O., \& Malinin, I. (2015). Nuzhno li predotvrashhat' teplovoj stress u dojnyh korov? [Is it necessary to prevent heat stress in dairy cows?]. Jeffektivnoe zhivotnovodstvo, 3-4(113), 18-20 (in Russian)

18. Lopatuhin, A. (2013). Izrailskiy opyit i ekonomicheskaya effektivnost vnedreniya ohladitelnyih sistem v molochnom jivotnovodstve [Israeli experience and cost-effectiveness of the introduction of cooling systems in dairy farming]. Molochnoe i myasnoe skotovodstvo, 3, 30-31 (in Russian)

19. Wang, X., Gao, H., Gebremedhin, K. G., Bjerg, B. S., Van Os, J., Tucker, C. B., \& Zhang, G. (2018). A predictive model of equivalent temperature index for dairy cattle (ETIC). Journal of Thermal Biology, 76, 165-170. doi:10.1016/j.jtherbio.2018.07.013

20. Bohmanova, J., Misztal, I., \& Cole, J. B. (2007). Temperature-Humidity Indices as Indicators of Milk Production Losses due to Heat Stress. Journal of Dairy Science, 90(4), 1947-1956. doi:10.3168/jds.2006-513

21. Fodor, N., Foskolos, A., Topp, C. F. E., Moorby, J. M., Pásztor, L., \& Foyer, C. H. (2018). Spatially explicit estimation of heat stress-related impacts of climate change on the milk production of dairy cows in the United Kingdom. PLOS ONE, 13(5), e0197076. doi:10.1371/journal.pone.0197076

22. Molodkovets, O., \& Zakharenko, M. (2016). Microclimate livestock buildings and premises for loose-boxed maintenance, forsed and voluntary milking cows. Scientific Messenger LNUVMBT named after S.Z. Gzhytskyj, 18, 4(72), 41-46 (in Ukrainian)

23. Voloshchuk, V. M., \& Khotsenko, A. V. (2017). Dynamika temperatury povitria ta vnutrishnikh elementiv konstruktsii korivnyka karkasnoho typu za dii faktoriv zovnishnoho seredovyshcha [Dynamics of air temperature and internal structural elements of the barn frame type on effects of environmental factors]. Visnyk Sumskoho natsionalnoho ahrarnoho universytetu. Seriia: Tvarynnytstvo, 5(2), 37-41(in Ukrainian)

24. Zakharenko, M., Voloshchuk, V., \& Khotsenko, A. (2018). Produktyvnist koriv zarubizhnoi selektsii za bezpryviaznoboksovoho utrymannia ta dii vysokoi temperatury povitria [The productivity of cows of foreign breeding is impairedboxing and exposure to high air temperature]. Naukovyi visnyk NUBiP Ukrainy. Seriia: Tekhnolohiia vyrobnytstva i pererobky produktsii tvarynnytstva, $0(271), 225-234$ (in Ukrainian)

25. Hodanovich, B. (2012). «Holodnyie» korovniki: uroki surovoy zimyi i jarkogo leta ["Cold" cowsheds: lessons from the harsh winter and hot summer]. Jivotnovodstvo Rossii. Spetsvyipusk, 25-28 (in Russian)

26. Schüller, L. K., \& Heuwieser, W. (2016). Measurement of heat stress conditions at cow level and comparison to climate conditions at stationary locations inside a dairy barn. Journal of Dairy Research, 83(3), 305-311. doi:10.1017/s0022029916000388

27. Gantner, V., Mijić, P., Kuterovac, K., Solić, D., \& Gantner, R. (2011). Temperature-humidity index values and their significance on the daily production of dairy cattle. Daily production of dairy cattle, Mljekarstvo 61 (1), 56-63.

28. Samal, L. (2013). Heat Stress in Dairy Cows - Reproductive Problems and Control Measures. International Journal of Livestock Research, 3(3), 14-23.

29. Ivanov, Ju. G., Zaginajlov, V. I., \& Ponizovkin, D. A. (2016). Avtomatizirovannaja sistema upravlenija jelektroprivodom mestnoj ventiljacii korovnika s upravljaemym vektorom potoka vozduha [Automated control system of cow farm electric local ventilation with vectoring airflow]. Vestnik VIJeSH, 4(25), 34-40 (in Russian)

30. Wolfenson, D., Flamenbaum, I., \& Berman, A. (1988). Dry Period Heat Stress Relief Effects on Prepartum Progesterone, Calf Birth Weight, and Milk Production. Journal of Dairy Science, 71(3), 809-818. doi:10.3168/jds.s00220302(88)79621-6

31. Puhach, A. M., Vysokos, M. P., Mylostyvyi, R. V, Tiupina, N. V., \& Kalinichenko, A. O. (2016). Device for humidifying and cooling air in animal housing. Ukraine Patent No. 108437 (in Ukrainian)

32. Milostivyj, R. V., Visokos, N. P., Priluckaja, E. V. \& Tihonenko, V. A. (2016). Meroprijatija po stabilizacii mikroklimata v zhivotnovodcheskih pomeshhenijah v zharkih pogodnyh uslovijah [Measures to stabilize the microclimate in livestock rooms in hot weather]. Prioritetnye i innovacionnye tehnologii v zhivotnovodstve - osnova modernizacii agropromyshlennogo kompleksa Rossii. Stavropol', 291-295 (in Russian).

33. Papanastasiou, D. K., Panagakis, P., Anestis, V., Bartzanas, T., Skoufos, I., Tzora, A., \& Kittas, C. (2018). Environmental conditions, potential heat-stress state and their relations in a sheep barn under hot climate. Agricultural Engineering International: CIGR Journal, Special issue: 1-13. 


\section{Р. В. Милостивий. Оцінка ймовірності теплового $\quad$ стресу $\quad$ в $\quad$ корів неізольованому корівнику в період літньої спеки}

Досліджували температуру і відносну вологість повітря в корівнику в період спеки, щоб визначити комфорт молочних корів шляхом розрахунку температурно-вологісного індексу (ТВI). Ці показники залежали від часу доби. Різнищя середніх температур всередині і зовні корівника не перевищувала 2 ... $3{ }^{\circ} \mathrm{C}$. У період спеки $\left(+36,9^{\circ} \mathrm{C}\right)$ в неізольованому корівнику було прохолодніше за рахунок тенту (який створював тіньовий захист від сонячних променів) і безперервної роботи вентиляторів великого діаметра. Відносна вологість повітря в приміщенні була вище в середньому на 1-14\%, ніж зовні, за рахунок виділення вологи тваринами і випаровування з оточуючих конструкцій. Тому ТВІ зовні і всередині корівника відрізнявся на 23 одиниці (P <0,05). Він перевищував комфортне значення (68) для корів протягом 18 год на добу, при максимальному зростанні до 81 од. ТВІ в самому приміщенні також відрізнявся. Різниця між центральними і бічними частинами неізольованого корівника сягала 3 ... 4 одиниці $(P<0,05)$. Це залежало від розташування його відносно сторін світу (з півночі на південь) і часу доби, тобто від ступеня прогрівання приміщення променями сонячного світла.

Ключові слова: неізольований корівник, молочні корови, зовнішнє середовище, жаркий клімат, температурно-вологісний індекс.

\section{Р.В. Милостивый. Оценка вероятности теплового стресса у коров в неизолированном коровнике в период жары}

Исследовали температуру и относительную влажность воздуха в коровнике в периоджары, чтобы определить комфорт молочных коров путем расчета температурно-влажностного индекса (ТВИ). Эти показатели зависели от времени суток. Разница средних температур внутри и снаружи коровника не превышала $2 \ldots 3^{\circ} \mathrm{C}$. В период зноя $\left(+36,9^{\circ} \mathrm{C}\right)$ в неизолированном коровнике было прохладнее за счет тента (который создавал теневую защиту от солнечных лучей) и непрерывной работы вентиляторов большого диаметра. Относительная влажность воздуха в помещении была выше в среднем на 1-14\%, чем снаружи, за счет выделения влаги животными и испарения с окружающих конструкций. Поэтому ТВИ снаружи и внутри коровника отличался на 2-3 единищы (P<0,05). Он превышал комфортное значение (68) для коров в течении 18 ч в сутки, при максимальном возрастании до 81 ед. ТВИ в самом помещении также отличался. Разница между центральными и боковыми частями неизолированного коровника достигала $3 . . .4$ единицы $(P<0,05)$. Это зависело от расположения его относительно сторон света (с севера на юг) и времени суток, то есть от степени прогревания помещения лучами солнечного света.

Ключевые слова: неизолированный коровник, молочные коровы, внешняя среда, жаркий климат, температурно-влажностный индекс.

Ця робота ліцензована Creative Commons Attribution 4.0 International License 